\title{
Germination, Growth and Yield Responses of Leaf Amaranth (Amaranthus hybridus) to Rates and Times of Poultry Manure Application
}

\author{
Folasade O. Adeyemi ${ }^{1}$, A. F. Kehinde-Fadare ${ }^{2}$ \& O. O. Olajide ${ }^{2}$ \\ ${ }^{1}$ Department of Soil Resources and Environmental Management, Ekiti State University, Ado-Ekiti, Nigeria \\ ${ }^{2}$ Department of Crop Production, Horticulture and Landscape Design, Ekiti State University, Ado-Ekiti, Nigeria \\ Correspondence: Folasade O. Adeyemi, Department of Soil Resources and Environmental Management, Ekiti \\ State University, Ado-Ekiti, Nigeria. E-mail: princesssadefisayo@yahoo.com
}

Received: October 26, $2021 \quad$ Accepted: November 12, $2021 \quad$ Online Published: November 21, 2021

doi:10.5539/sar.v10n4p40

URL: https://doi.org/10.5539/sar.v10n4p40

\begin{abstract}
Manures are more environment-friendly and effective in improving soil fertility, hence their recent preference over inorganic fertilizers. Poultry manure is believed to be the most valuable manure produced by livestock. However, the application had always been only before sowing, unlike the inorganic fertilizers that are, generally, applied after sowing/planting of crops. Therefore, the effects of broiler droppings applied at different rates and times were evaluated on seed germination, growth and yield of leaf amaranths, during the raining season of year 2019. Broilers droppings were applied at 0, 30 and 50 tha $^{-1}$, at 1 and 2 week (-s) before sowing, at sowing and 1 and 2 (week)s after sowing of amaranth seeds. The experiment was factorial and treatments were replicated thrice in a randomized complete block design. Growth parameters measured were: Plant height, number of leaves, stem girth, leaf area, number of germinated seeds, and yield were measured at 7, 8 and 9 weeks after sowing (WAS). The data generated were subjected to ANOVA at $\alpha_{0.05}$. At 7 WAS, application of 50 tha $^{-1}$ manure $^{-1}$ at sowing produced the highest plant height $(17 \mathrm{~cm})$, stem girth $(7.40 \mathrm{~cm})$, number of harvested stands $(18.33)$ and marketable yield $\left(7.95\right.$ tha $\left.^{-1}\right)$ with significant differences. At 8 WAS, the highest yield $\left(5.83\right.$ tha $^{-1}$ was obtained from plots treated with 30 tha $^{-1}$ of poultry dung applied at 2 weeks before sowing while more seeds (27) germinated on both plots treated with 50 t/ha of broiler droppings applied at sowing and 1 WAS. The best recorded values for number of germinated seeds (27) and yield $\left(2.83\right.$ tha $\left.^{-1}\right)$ at 9 WAS were obtained from 50 tha $^{-1}$ of broiler droppings applied at sowing. $50 \mathrm{t} / \mathrm{ha}$ of broiler droppings, at sowing compared well with poultry droppings applied at any rate before sowing.
\end{abstract}

Keywords: poultry manure, rate, time of application, germination and growth, yield, leaf amaranth

\section{Introduction}

Growing and harvesting agricultural crops continuously, implies that most nutrients, particularly, N, P and K are removed from the soil. Nutrient removal often results in soil fertility decline, if replenishment with inorganic or organic nutrient inputs is not done or inadequately done (Zingore et al., 2003). Low soil fertility can be maintained through application of manure, other organic materials, inorganic fertilizers, lime and the inclusion of legumes in the cropping system or a combination of all these factors (Alain, 2004). However, in many parts of the world, particularly Nigeria, the availability, use and profitability of inorganic fertilizers have been low (Isherwood, 2000; Hartemink, 2004; AdeOluwa and Adeogun, 2010). This resultantly caused intensification of land use and expansion of crop cultivation into marginal areas due to urban development. As a result, soil fertility decline is perceived to be widespread, particularly in the tropics such that the use of fertilizers to supplement soil nutrients, especially $\mathrm{N}$ required for succulent green leafy growth of vegetables but whose deficiency is widespread; is a component of improved soil management practices (Ahmad et al, 2016). Hence, the search for alternative cheaper sources of nutrients has become a necessity. Thus, the recommendations had been $60 \mathrm{~kg} \mathrm{~N} / \mathrm{ha}$ for leaf Amaranth plants (Amaranthus cruentus (hybridus L.) to be harvested by uprooting and $100 \mathrm{Kg}$ for the vegetables to be harvested by repeated cutting, respectively (Olufolaji and Denton, 2000). Soil fertility decline is considered as an important cause for low productivity of many soils. It has not received the same amount of research attention as soil erosion, possibly because soil fertility decline is less visible and less 
spectacular and also more difficult to assess (Alfred, 2006). The decline in soil organic matter content is becoming a major process of soil degradation, particularly in Nigeria. Nutrient depletion is the main reason why crop production systems are not sustainable. Therefore, soil fertility restoration must target raising the available nutrients status and maintaining organic matter content at high levels. Common agricultural practices associated with mechanized large open farms; continuous deep tillage, excessive use of chemical fertilizers and agro-chemicals and luxury irrigation had been indicted for soil degradation and pollution of water resources and the atmosphere. A reversal of this trend will require the use of natural processes and optimization of their functions to sustain productivity on the farms.

Soil fertility is strongly influenced by the accumulation of organic wastes, ashes, night soil and by-products close to living areas (Alain, 2004). Chemical fertilizers and other soil amendments are 'green revolution' inputs that have raised farm yields substantially, depending on management practices and environmental conditions. The relative costs and ease of availability are factors that affect the form of fertilizers selected (Peter et al., 2004) even as controversy rages over organic versus inorganic sources of nutrients. Plants do not recognize the difference between organic and inorganic sources of nutrients and their tiny roots can absorb only nutrients that have been broken down into inorganic, water soluble forms. Many experiments conducted, however to compare organic manures with chemical fertilizers to supply an equivalent amount of $\mathrm{N}$, the results had often favoured manure application because of its ability to modify the soil physical, biological and chemical properties (Ahn, 1993). Also farmers and gardeners have long recognized the role of manure in replacing nutrients on depleted soils by continuous cropping. Large quantities of organic waste materials are generated in the agricultural value-chain and several studies have demonstrated the positive effects of the application on soil properties and crop performance which supported the use as soil amendments (Hossain et al., 2017). The benefits include: higher availability of plant nutrients, better water holding capacity, cation exchange capacity (CEC), lower bulk density and fostering beneficial microorganisms (Pimentel et al., 2005); pH stabilization and faster water infiltration rate due to enhanced soil aggregation (Pacini et al., 2003; Wood et al., 2005); increase in the soil organic matter and reduced nitrate runoff (Drinkwater et al., 1998). These organic nutrient sources (livestock manure, crop residues, municipal wastes, biomass transfer etc.) may be used as alternatives to chemical fertilizers. The most popular are manures derived from livestock (cattle, poultry, sheep and goats). The states located in the savannah zone have large populations of cattle, sheep and goats whose droppings (manures) have been used by the farmers. States in the (humid) forest zone are not conducive to large ruminant animals but favour poultry production (Uche, 1991).

Poultry manure is the most valuable of all manures produced by livestock and used as sources of plant nutrients and as soil amendments (Charles and Donald, 2012). Poultry droppings are easy and cheap to get and do not burn crops like inorganic fertilizers. Poultry manure is a more concentrated source of nutrients, especially N, P, $\mathrm{K}$ and $\mathrm{Ca}$. Poultry manure contains organic matter and nutrients which are available for improving and conditioning the soil for the nutrient supply of the crop and thereby increasing crop yield (Alasiri and Ogunkeyede, 1999; Fawole, 2015). The nutrients in poultry manure, like other organic nutrient sources, are released more slowly and over a longer period of time than most commercial/synthetic fertilizers (Fawole, 2015). Being naturally organic, it may not need composting and can be applied directly from the farm to the fields (Prabu, 2009). All nutrients contained in poultry manure take the form of available compounds. The availability of most nutrients in poultry manure is fairly consistent except for $\mathrm{N}$ which occurs in several forms that can be lost under different management or environmental conditions (Soilfacts, 2012). Poultry manure, had been used alone (Busari et al., 2004; Ano and Agwu, 2006; Fawole, 2015) and also in combination with some other materials in form of composts (Adeoye et al., 2004; Agunsoye et al., 2009; Eneje and Azu, 2009) to improve soil nutrient status and crop production.

Omolayo et al., (2011) in a study to evaluate the effects of poultry manure from different sources on the growth and marketable yield of leaf amaranth (Amaranthus cruentus (hybridus) l.) amaranthaceae, observed that application of poultry manure especially broilers at $30 \mathrm{MT} / \mathrm{ha}$ improved vegetative growth and yield of Amaranthus. They discovered that poultry dungs from different sources at different levels significantly $(\mathrm{P}=0.05)$ increased plant height, number of leaves, stem girth and marketable yield of leaf amaranths. They therefore recommended broilers droppings at 30MT/ha for farmers in improving the growth of leaf amaranths.

\subsection{Amaranthus}

Amaranthus is an ancient crop which originated in central America (Grubben, 2004; Aderolu et al., 2013) but at present, it is a widespread traditional vegetable in all countries of tropical Africa especially Benin, Togo, Sierra Leone, and very importantly, in many lowland areas e. g southern Nigeria, Congo, Kenya and Tanzania (Grubben, 2004). Leaves and young seedlings are cut and cooked as spinach, mixed with fish or meat and added 
to soups. Traditionally in arid regions, the leaves are dried and the leaf powder is used in sauces during the dry season. A tea made from amaranthus leaves is astringent. It is used in the treatment of intestinal bleeding, diarrhea and excessive menstruation (Putnam et al., 2018.) Amaranth is diuretic. Regular consumption of amaranth reduces blood pressure, cholesterol levels and improves the body's antioxidant status and immunity (Martirosyan et al., 2007). Vegetable amaranths are recommended as a good food with medicinal properties for young children, lactating mothers and for patients with constipation, fever, hemorrhage, anemia or kidney complaints. In Senegal, the roots are boiled with honey as a laxative for infants. In Ghana, the water of macerated plants is used as a wash to treat pains in the limbs. In Ethiopia, amaranthus is used as a tapeworm-expellent. In Sudan, the ash from the stems is used as a wound dressing. In Gabon, heated leaves were used on tumors (Grubben, 2004).

\subsection{Justification of the Study}

Amaranths are consumed to a very great extent in the southern part of Nigeria, especially in Ekiti State where this study was carried out. Farmers in the southern part of Nigeria, especially Ekiti State make use of inorganic fertilizers to aid in the production of amaranths. This at times makes the production of these vegetables to be an expensive or a difficult task for the poor farmers because the availability, use and profitability of inorganic fertilizers have been low (Isherwood, 2000; Hartemink, 2004; AdeOluwa and Adeogun, 2010). On the other hands, the available poultry houses and pens are continuous sources of poultry dung which are routinely burnt and thereby causing air pollution, whereas these poultry droppings had been evaluated to be the most valuable of all manures produced by livestock (Charles and Donald, 2012). Fawole et al. (2019 and 2021) confirmed the beneficial effects of organic sources, including poultry droppings on the nitrogen and phosphorus contents of soils, respectively. Likewise, Omolayo et al., (2011) recommended application of $30 \mathrm{MT} / \mathrm{ha}$ of broiler droppings for optimum and sustainable production of vegetables, as it was observed that application of poultry manure, particularly broilers at $30 \mathrm{MT} / \mathrm{ha}$ improved vegetative growth and yield of Amaranthus. In the same manner, the main and residual effects of poultry droppings (especially broiler droppings), had been reported to improve soils' physical and chemical properties and hence, yields of amaranth (Fawole, 2015). More still, Naishima et al., (2019) recommended poultry droppings as the most suitable organic manure for nurturing juvenile seedlings of $E$. camaldulensis in the nursery for plantation purposes. Poultry manure is applied directly from the farm to the fields thereby reducing stress (Prabu, 2009). The application of organic manures including poultry dung had however been performed two or three weeks before the planting of crops (Adekiya and Agbede, 2017); with the belief that the organic material might need to cure before crops are planted. However, proper timing of nutrient application ensures the availability of the nutrients when the crop needs them. This will also avoid nutrient losses which can be before and after periods of crop demand which in the long run result in wastage of resources (Ndukwe et al., 2011). Thus, there is a need to investigate which effects the application of poultry droppings at different times (before, during and after sowing of the vegetable amaranth) could have on the germination, growth and yield of amaranth in order to make suggestions and recommendations to farmers on its use in terms of application rate and time.

This study therefore accessed the effects of poultry droppings applied at different rates and times on the: seed germination growth and yield of leaf amaranth (Amaranthus hybridus).

\section{Materials and Methods}

The study was carried out at the Teaching and Research farm of Ekiti State University, Ado-Ekiti, Nigeria, in the rainy period (April-July) of the year 2019. The study area is located at latitude $7^{\circ} 31^{\prime} \mathrm{N}$ longitude $5^{\circ} 13^{\prime} \mathrm{E}$ and covers an area of about 20 hectares in the rain forest zone of southwestern Nigeria. The area experiences a tropical climate with distinct wet and dry seasons. The dry season spans from November to early March and raining season from late March or early April to October with a dry spell in August (Not prominent nowadays). The mean annual total rainfall is about $1367 \mathrm{~mm}$ received over 112 days. The temperature is almost uniform throughout the year with very little deviation from the mean annual of $27^{\circ} \mathrm{C}$. February and March are the hottest months with the mean temperature of $28^{\circ} \mathrm{C}$ and $27^{\circ} \mathrm{C}$ respectively. The mean annual total number of sunshine is about 5 hours and the mean annual radiation is about $130 \mathrm{kcal} / \mathrm{cm}^{2} / y e a r$ (Fasina et al., 2005). The geology is dominated by crystalline rocks, which form part of the basement complex of southwestern Nigeria. They are mostly granitic rock materials. The area mostly has maximum elevation of about 730 metres and relative relief of about 395 metres. The major soil type identified, according to Smyth and Montgomery (1962) and FAO/UNESCO Legend (1988) are Iregun, Apomu and Ondo series (Fasina et al., 2005). The main vegetation of the area is forest mixed with various types of bush-regrowth, grasses and creepers. The agricultural economy is dominated by the cultivation of arable crops (e.g. yam, cassava, rice, maize, vegetables, including Amaranths) and permanent tree crops (cocoa, kola and oil palm). 
Surface $(0-15 \mathrm{~cm})$ soil samples were randomly taken, air-dried and passed through $2 \mathrm{~mm}$ sieve. The soils were analyzed using the procedures described in IITA (1982) for $\mathrm{pH}$ in 1:2 soil- $\mathrm{KCl}$ medium, particle size distribution by the hydrometer method, organic carbon by the wet dichromate oxidation, total $\mathrm{N}$ by macro- Kjeldhal method, available $\mathrm{P}$ by the Bray P-1 extraction while exchangeable cations were extracted with $1 \mathrm{~N} \mathrm{NH}_{4} \mathrm{OAc}$ and determined with atomic absorption spectrophotometer. The exchangeable acidity (EA) was determined by the titration method. The effective cation exchange capacity (ECEC) was the sum of the exchangeable bases $(\mathrm{K}+\mathrm{Na}+\mathrm{Ca}+\mathrm{Mg})$ and EA and percent base saturation calculated as the sum of the exchangeable bases expressed as a percentage of ECEC.

The poultry droppings were collected from the Teaching and Research Farm, Ekiti State University, Ado-Ekiti. Sample of the droppings was collected and analysed for $\mathrm{pH}$, organic carbon, total $\mathrm{N}, \mathrm{P}, \mathrm{Ca}, \mathrm{Mg}$ and $\mathrm{K}$. Poultry droppings were air-dried, milled and analyzed for $\mathrm{pH}$ in water at 1:2 ratio, total carbon by chromic acid wet digestion method, total $\mathrm{N}$ by the micro-Kjeldahl method, total $\mathrm{P}, \mathrm{Ca}$, magnesium $(\mathrm{Mg})$ and $\mathrm{K}$ by wet digestion using concentrated nitric, perchloric and sulphuric acid mixture at a ratio of 25: 5: 5 respectively. $P$ in the digests was determined by vanado-molybdate method, $\mathrm{K}$ was determined by flame photometry while $\mathrm{Ca}$ and $\mathrm{Mg}$ were determined by atomic absorption spectrophotometry (Udo et al., 2010).

The site was cleared manually and the residues packed. Beds of $3 \mathrm{~m}$ x $2 \mathrm{~m}$ were made with $1 \mathrm{~m}$ paths in between the blocks and plots. There were 5 poultry droppings application times and the manure was broadcast at the stipulated application times: 2 and 1 week before sowing (WBS), at sowing, and 1 and 2 weeks after sowing (WAS). The manure was applied at the rates of 0,30 and 50 MT/ha, for each assigned application time. So, there were fifteen treatments replicated three times. The treatments were arranged as a factorial experiment, with three replicates, in a Randomized Complete Block Design. Seeds of leaf amaranth (NHAc23) were mixed with dry sand and broadcast uniformly on the beds at the rate of $2.5 \mathrm{~kg} / \mathrm{ha}$. Weeding was done manually at 3 weeks interval throughout the period of the study.

Table 1. Description of the treatments used in the study

\begin{tabular}{|c|c|}
\hline Treatments & Description \\
\hline 1 & $50 \mathrm{MT} / \mathrm{ha}$ applied 2 weeks before sowing \\
\hline 2 & $50 \mathrm{MT} / \mathrm{ha}$ applied 1 week before sowing \\
\hline 3 & $50 \mathrm{MT} / \mathrm{ha}$ applied at sowing \\
\hline 4 & $50 \mathrm{MT} / \mathrm{ha}$ applied 1 week after sowing \\
\hline 5 & $50 \mathrm{MT} / \mathrm{ha}$ applied 2 weeks after sowing \\
\hline 6 & $30 \mathrm{MT} / \mathrm{ha}$ applied 2 weeks before sowing \\
\hline 7 & $30 \mathrm{MT} / \mathrm{ha}$ applied 1 week before sowing \\
\hline 8 & $30 \mathrm{MT} / \mathrm{ha}$ applied at sowing \\
\hline 9 & $30 \mathrm{MT} / \mathrm{ha}$ applied 1 week after sowing \\
\hline 10 & $30 \mathrm{MT} / \mathrm{ha}$ applied 2 weeks after sowing \\
\hline 11 & $0 \mathrm{MT} / \mathrm{ha}$ applied 2 weeks before sowing \\
\hline 12 & $0 \mathrm{MT} / \mathrm{ha}$ applied 1 week before sowing \\
\hline 13 & $0 \mathrm{MT} / \mathrm{ha}$ applied at sowing \\
\hline 14 & 0 MT/ha applied 1 week after sowing \\
\hline 15 & 0 MT/ha applied 2 weeks after sowing \\
\hline
\end{tabular}

Data were taken on plant height, number of leaves, stem girth, leaf area, germinated seeds and marketable yield. These data were taken at 7,8 and 9 weeks after sowing (WAS). Harvesting of the leaf amaranth was by uprooting. The data generated were subjected to analysis of variance (ANOVA) and the means separated using Duncan Multiple Range Test (DMRT) at $P=0.05$.

\section{Results}

There were a total of 15 treatments evaluated in the experiment. The poultry manure was basic with moderate quantities of the essential nutrients needed for good performance of leaf vegetables, including amaranthus (Table 2). The soil is a sandy loam and slightly acidic. It is rich in organic matter $(22.4 \mathrm{~g} / \mathrm{kg}), \mathrm{N}(2.4 \mathrm{~g} / \mathrm{kg})$ and $\mathrm{K}(0.2$ $\mathrm{cmol} / \mathrm{kg}$ ) and all exchangeable bases but low in $\mathrm{P}(4.46 \mathrm{mg} / \mathrm{kg}$ ) (Table 3$)$

There were significant differences in the plant height that was measured at 7 WAS (Table 4). The tallest leaf Amaranths $(17.00 \mathrm{~cm})$ were produced by 50 and $30 \mathrm{MT} / \mathrm{ha}$ applied at sowing which were significantly different from 50 and $30 \mathrm{MT} / \mathrm{ha}$ applied at 2 WAS $(4.33 \mathrm{~cm})$ and from all height values obtained from the control plots. 
The shortest plants were from 50 and $30 \mathrm{MT} / \mathrm{ha}$ applied at 2 WAS which were significantly different from 50 and $30 \mathrm{MT} / \mathrm{ha}$ at $2 \mathrm{WBS}$, at sowing and even the control plots. The highest number of leaves (54.33) were obtained from $50 \mathrm{MT} / \mathrm{ha}$ applied at $2 \mathrm{WBS}$. These were significantly different from 50 (2.33) and $30 \mathrm{MT} / \mathrm{ha}$ (1.33) applied at 2 WAS and from the values obtained from all the control plots. The fewest leaves (1.33) were obtained from $30 \mathrm{MT} / \mathrm{ha}$ applied at $2 \mathrm{WAS}$ which was not significantly different from $50 \mathrm{MT} / \mathrm{ha}$ applied at $2 \mathrm{WAS}$ and all control plots. The best stem girth $(7.40 \mathrm{~cm})$ values were obtained from $50 \mathrm{MT} / \mathrm{ha}$ applied at sowing and was significantly different from $50(3.83 \mathrm{~cm})$ and $30(5.13 \mathrm{~cm}) \mathrm{MT} / \mathrm{ha}$ applied at $2 \mathrm{WAS}$ and the control plots. Amaranths from $50 \mathrm{MT} / \mathrm{ha}$ applied at 2 WAS were the thinnest and were not significantly different from only the values obtained from $30 \mathrm{MT} / \mathrm{ha}$ applied at 2 WAS and those obtained from all the control plots. There were significant differences in the leaf area. The biggest leaves $\left(137.83 \mathrm{~cm}^{2}\right)$ were obtained from $50 \mathrm{MT} / \mathrm{ha}$ applied at 1 WAS and were significantly different from those obtained from $50 \mathrm{MT} /$ ha applied at sowing which were 71.03 $\mathrm{cm}^{2}$. The smallest leaves were from the control plots. The germination of amaranth seeds (measured by the number of vegetable stands that were harvested) was highest (18.33) in the plots treated with $50 \mathrm{MT} / \mathrm{ha}$ of poultry droppings applied at sowing and was significantly different from both 50 (4.00) and $30 \mathrm{MT} / \mathrm{ha}(8.17)$ applied at 2 weeks after sowing. The yield of Amaranth vegetables at 7 WAS also showed significant differences. Vegetables from $50 \mathrm{MT} / \mathrm{ha}$ applied at sowing gave the highest yield $(7.95 \mathrm{t} / \mathrm{ha})$ which were significantly different from $50 \mathrm{MT} / \mathrm{ha}$ applied at $2 \mathrm{WAS}(0.22 \mathrm{t} / \mathrm{ha}), 30 \mathrm{MT} / \mathrm{ha}$ applied at $1(2.50 \mathrm{t} / \mathrm{ha})$ and $2 \mathrm{WBS}, 30 \mathrm{MT} / \mathrm{ha}(0.55 \mathrm{t} / \mathrm{ha})$ applied at 2 WAS $(0.67 \mathrm{t} / \mathrm{ha})$ and those from the control plots. The marketable yield recorded from $50 \mathrm{MT} / \mathrm{ha}$ applied at 2 WAS was the lowest.

Table 2. Chemical composition of poultry manure used in the study

\begin{tabular}{ll}
\hline Parameters & Values \\
\hline $\mathrm{PH}$ & 8.00 \\
Organic carbon g/kg & 18.5 \\
$\mathrm{~N}$ & 2.32 \\
$\mathrm{C}: \mathrm{N}$ & 7.97 \\
$\mathrm{P}$ & 0.52 \\
$\mathrm{~K}$ & 1.23 \\
$\mathrm{Ca}$ & 1.10 \\
$\mathrm{Mg}$ & 0.64 \\
$\mathrm{Na}$ & 0.07 \\
\hline
\end{tabular}

Table 3. Some physical and chemical properties of soils of the experimental site

\begin{tabular}{ll}
\hline Parameters & Values \\
\hline $\mathrm{pH}(\mathrm{KCl})$ & 5.6 \\
$\mathrm{pH}\left(\mathrm{H}_{2} \mathrm{O}\right)$ & 6.3 \\
Organic matter $(\mathrm{g} / \mathrm{kg})$ & 22.4 \\
Total N $(\mathrm{g} / \mathrm{kg})$ & 2.4 \\
Available $\mathrm{P}(\mathrm{mg} / \mathrm{kg})$ & 4.46 \\
Exchangeable cations $(\mathrm{cmol} / \mathrm{kg})$ & \\
Calcium & 2.7 \\
Magnesium & 0.4 \\
Sodium & 0.6 \\
Potassium & 0.2 \\
Exchangeable Acidity & 1.6 \\
ECEC (cmol/kg) & 5.5 \\
Base saturation (\%) & 70.9 \\
Sand $(\mathrm{g} / \mathrm{kg})$ & 812 \\
Silt & 134 \\
Clay & 54 \\
Textural Class (USDA) & Sandy loam \\
\hline
\end{tabular}


Table 4. Responses of leaf Amaranth to application of poultry droppings at 7 WAS

\begin{tabular}{lllllll}
\hline Treatment & $\begin{array}{l}\text { Plant } \\
\text { height }(\mathbf{c m})\end{array}$ & $\begin{array}{l}\text { Number } \\
\text { of leaves }\end{array}$ & $\begin{array}{l}\text { Stem } \\
\text { girth }(\mathbf{c m})\end{array}$ & $\begin{array}{l}\text { Leaf } \\
\text { area }\left(\mathbf{c m}^{2}\right)\end{array}$ & $\begin{array}{l}\text { Number of } \\
\text { Harvested Stands }\end{array}$ & $\begin{array}{l}\text { Marketable } \\
\text { Yield (MT/ha) }\end{array}$ \\
\hline $50 \mathrm{t} / \mathrm{ha}$ at $2 \mathrm{WBS}$ & $16.00 \mathrm{ab}$ & $54.33 \mathrm{a}$ & $6.87 \mathrm{ab}$ & $103.80 \mathrm{abc}$ & $17.50 \mathrm{a}$ & $5.33 \mathrm{abcde}$ \\
$50 \mathrm{t} / \mathrm{ha}$ at $1 \mathrm{WBS}$ & $14.17 \mathrm{abc}$ & $35.00 \mathrm{abcd}$ & $6.17 \mathrm{abc}$ & $135.67 \mathrm{ab}$ & $16.00 \mathrm{ab}$ & $6.78 \mathrm{ab}$ \\
$50 \mathrm{t} / \mathrm{ha}$ at sowing & $17.00 \mathrm{a}$ & $50.67 \mathrm{ab}$ & $7.40 \mathrm{a}$ & $71.03 \mathrm{bc}$ & $18.33 \mathrm{a}$ & $7.95 \mathrm{a}$ \\
$50 \mathrm{t} / \mathrm{ha}$ at $1 \mathrm{WAS}$ & $13.00 \mathrm{abc}$ & $45.33 \mathrm{abc}$ & $6.10 \mathrm{abcd}$ & $137.83 \mathrm{a}$ & $18.00 \mathrm{a}$ & $6.50 \mathrm{abc}$ \\
$50 \mathrm{t} / \mathrm{ha}$ at $2 \mathrm{WAS}$ & $4.33 \mathrm{~d}$ & $2.33 \mathrm{c}$ & $3.83 \mathrm{e}$ & $73.50 \mathrm{abc}$ & $4.00 \mathrm{e}$ & $0.22 \mathrm{f}$ \\
$30 \mathrm{t} / \mathrm{ha}$ at $2 \mathrm{WBS}$ & $16.50 \mathrm{a}$ & $53.33 \mathrm{a}$ & $6.67 \mathrm{ab}$ & $99.07 \mathrm{abc}$ & $12.83 \mathrm{abc}$ & $0.55 \mathrm{f}$ \\
$30 \mathrm{t} / \mathrm{ha}$ at $1 \mathrm{WBA}$ & $11.67 \mathrm{abc}$ & $35.00 \mathrm{abcd}$ & $6.37 \mathrm{abc}$ & $101.27 \mathrm{abc}$ & $10.00 \mathrm{abcde}$ & $2.50 \mathrm{bcdef}$ \\
$30 \mathrm{t} / \mathrm{ha}$ at sowing & $17.00 \mathrm{a}$ & $53.33 \mathrm{a}$ & $6.90 \mathrm{ab}$ & $104.67 \mathrm{abc}$ & $11.00 \mathrm{abcde}$ & $6.17 \mathrm{abc}$ \\
$30 \mathrm{t} / \mathrm{ha}$ at $1 \mathrm{WAS}$ & $13.00 \mathrm{abc}$ & $47.67 \mathrm{ab}$ & $6.87 \mathrm{ab}$ & $102.23 \mathrm{abc}$ & $13.53 \mathrm{abc}$ & $5.45 \mathrm{abcd}$ \\
$30 \mathrm{t} / \mathrm{ha}$ at $2 \mathrm{WAS}$ & $4.33 \mathrm{~d}$ & $1.33 \mathrm{e}$ & $5.13 \mathrm{bcde}$ & $97.97 \mathrm{abc}$ & $8.17 \mathrm{bcde}$ & $0.67 \mathrm{def}$ \\
$0 \mathrm{t} / \mathrm{ha}$ at $2 \mathrm{WBS}$ & $11.00 \mathrm{bc}$ & $20.33 \mathrm{bcde}$ & $4.70 \mathrm{cde}$ & $60.83 \mathrm{c}$ & $5.00 \mathrm{de}$ & $0.95 \mathrm{def}$ \\
$0 \mathrm{t} / \mathrm{ha}$ at $1 \mathrm{WBS}$ & $10.00 \mathrm{c}$ & $15.67 \mathrm{cde}$ & $4.37 \mathrm{de}$ & $68.33 \mathrm{c}$ & $5.00 \mathrm{de}$ & $1.22 \mathrm{def}$ \\
$0 \mathrm{t} / \mathrm{ha}$ at sowing & $10.00 \mathrm{c}$ & $11.33 \mathrm{de}$ & $5.10 \mathrm{bcde}$ & $42.77 \mathrm{c}$ & $10.33 \mathrm{abcde}$ & $2.17 \mathrm{bcdef}$ \\
$0 \mathrm{t} / \mathrm{ha}$ at $1 \mathrm{WAS}$ & $10.00 \mathrm{c}$ & $9.00 \mathrm{de}$ & $4.37 \mathrm{de}$ & $70.97 \mathrm{bc}$ & $6.00 \mathrm{cde}$ & $1.22 \mathrm{def}$ \\
$0 \mathrm{t} / \mathrm{ha}$ at $2 \mathrm{WAS}$ & $9.33 \mathrm{~cd}$ & $5.00 \mathrm{de}$ & $5.13 \mathrm{bcde}$ & $60.63 \mathrm{c}$ & $5.67 \mathrm{cde}$ & $1.78 \mathrm{cdef}$ \\
\hline
\end{tabular}

Means within the same column followed by the same letters are not significantly different at $P=0.05$

Similar trend as in 7 WAS were observed at 8 WAS (Table 5). There were significant differences in plant height, Number of leaves, stem girth, leaf area and yield. The tallest vegetables $(18.33 \mathrm{~cm})$ which were produced from $50 \mathrm{MT} / \mathrm{ha}$ applied at sowing were significantly different from $50 \mathrm{MT} / \mathrm{ha}$ applied at $2 \mathrm{WAS}(4.00 \mathrm{~cm}), 30 \mathrm{MT} / \mathrm{ha}$ applied at 2 WAS $(8.17 \mathrm{~cm})$ and the control plots. The shortest plants were obtained from $50 \mathrm{MT} / \mathrm{ha}$ applied at 2 WAS. Even though there were not much significant differences in the values obtained for number of leaves of leaf Amaranth at $7 \mathrm{WAS}, 50 \mathrm{MT} / \mathrm{ha}$ applied at sowing and $50 \mathrm{MT} / \mathrm{ha}$ applied at $1 \mathrm{WAS}$ gave the highest values (27.00) closely followed by $30 \mathrm{MT} / \mathrm{ha}$ applied at sowing (26.00). The least number of leaves (1.67) were obtained from $30 \mathrm{MT} / \mathrm{ha}$ applied at $2 \mathrm{WAS}$. The stem girth at 7 WAS were also significantly different from one another. The thickest stalks were from $50 \mathrm{MT} / \mathrm{ha}$ applied at $2 \mathrm{WBS}(10.80 \mathrm{~cm})$. They were significantly different from all other treatments except $50 \mathrm{MT} / \mathrm{ha}$ applied at $1 \mathrm{WBS}(6.03 \mathrm{~cm}), 30 \mathrm{MT} / \mathrm{ha}$ applied at $1 \mathrm{WBS}(6.53 \mathrm{~cm})$ and $30 \mathrm{MT} / \mathrm{ha}$ applied at sowing $(6.43 \mathrm{~cm})$. The thinnest vegetables $(1.63 \mathrm{~cm})$ were from $30 \mathrm{MT} / \mathrm{ha}$ applied at 2 WAS but were only significantly different from $50 \mathrm{MT} / \mathrm{ha}$ applied at $2 \mathrm{WBS}$ which gave the highest value for the stem girth. There were significant differences in the leaf areas measured at 8 WAS. The biggest leaves (129.67 $\mathrm{cm}^{2}$ ) were from $50 \mathrm{MT} / \mathrm{ha}$ applied at 1 WAS though only significantly different from the values for the control plots which gave the smallest leaves. The highest number of harvested stands (27.05) was recorded from 50 $\mathrm{MT} / \mathrm{ha}$ of the organic material applied at sowing and 1 WAS. The least number of harvested stands was 2.17, which were recorded from $30 \mathrm{MT} / \mathrm{ha}$ of the organic waste applied at 2 WAS. The best marketable yield value of $5.83 \mathrm{t} / \mathrm{ha}$ was recorded from $30 \mathrm{MT} / \mathrm{ha}$ applied at $2 \mathrm{WBS}$. This was significantly different from all other treatments except $50 \mathrm{MT} / \mathrm{ha}$ applied at $2 \mathrm{WBS}(3.22 \mathrm{t} / \mathrm{ha})$ and $30 \mathrm{MT} / \mathrm{ha}$ applied at sowing $(3.55 \mathrm{t} / \mathrm{ha})$. The least yield was recorded from $30 \mathrm{MT} / \mathrm{ha}$ applied at 1 and 2 WAS.

The tallest vegetables $(16.00 \mathrm{~cm}$ ) at 9 WAS (Table 6) were from $50 \mathrm{MT} / \mathrm{ha}$ applied at sowing followed closely by vegetables from $50 \mathrm{MT} / \mathrm{ha}$ applied at $1 \mathrm{WAS}(15.67 \mathrm{~cm})$. Though, they were significantly different from only vegetables from 50 and $30 \mathrm{MT} / \mathrm{ha}$ applied at $2 \mathrm{WAS}$ and the control plots. The lowest vegetable height was recorded from $50 \mathrm{MT} / \mathrm{ha}$ applied at $2 \mathrm{WAS}(3.03 \mathrm{~cm}) .50 \mathrm{MT} / \mathrm{ha}$ applied at sowing gave the highest number of leaves at 9 WAS, although not significantly different from most of the other treatments but was significantly different from 50 and $30 \mathrm{MT} / \mathrm{ha}$ applied at 2 WAS (8.33 and 1.67 respectively) and all the control plots as was recorded for plant height. The fewest leaves were from $30 \mathrm{MT} / \mathrm{ha}$ applied at $2 \mathrm{WAS}$. There was significant difference in stem girth at 9 WAS with $50 \mathrm{MT} / \mathrm{ha}$ applied at 2 WAS giving the thickest vegetables of $5.63 \mathrm{~cm}$. This was significantly different from $50 \mathrm{MT} / \mathrm{ha}$ applied at 1 and $2 \mathrm{WAS}, 30 \mathrm{MT} / \mathrm{ha}$ applied at $2 \mathrm{WAS}$ and the control plots. There were not much significant differences in the leaf areas of Amaranth vegetables measured at 9 WAS. The biggest leaves were produced by $50 \mathrm{MT} / \mathrm{ha}$ applied at $1 \mathrm{WAS}\left(124.67 \mathrm{~cm}^{2}\right)$, followed closely by 50 MT/ha applied at 1 WBS $\left(123.67 \mathrm{~cm}^{2}\right)$ but they were only significantly different from some of the leaves obtained from the control plots. More vegetable stands germinated and were harvested at 9 WAS from the plots treated with $50 \mathrm{MT} / \mathrm{ha}$ of poultry droppings applied at sowing. There were no significant differences in the yield of the leaf amaranth at 8 WAS but the highest yield $(2.83 \mathrm{t} / \mathrm{ha})$ was recorded from $30 \mathrm{MT} / \mathrm{ha}$ applied at sowing 
while the lowest yield was from one of the control plots followed by 50 MT/ha applied at 2 WAS.

Table 5. Responses of leaf Amaranth to application of poultry droppings at 8 WAS

\begin{tabular}{lllllll}
\hline Treatments & $\begin{array}{l}\text { Plant } \\
\text { height }(\mathbf{c m})\end{array}$ & $\begin{array}{l}\text { Number } \\
\text { of leaves }\end{array}$ & $\begin{array}{l}\text { Stem } \\
\text { girth }(\mathbf{c m})\end{array}$ & $\begin{array}{l}\text { Leaf } \\
\text { area }\left(\mathbf{c m}^{2}\right)\end{array}$ & $\begin{array}{l}\text { Number of } \\
\text { Harvested stands }\end{array}$ & $\begin{array}{l}\text { Marketable } \\
\text { Yield }(\mathbf{M T} / \mathrm{ha})\end{array}$ \\
\hline $50 \mathrm{t} / \mathrm{ha}$ at $2 \mathrm{WBS}$ & $17.50 \mathrm{a}$ & $20.00 \mathrm{ab}$ & $10.80 \mathrm{a}$ & $98.47 \mathrm{ab}$ & $20.00 \mathrm{ab}$ & $3.22 \mathrm{abc}$ \\
$50 \mathrm{t} / \mathrm{ha}$ at $1 \mathrm{WBS}$ & $16.00 \mathrm{ab}$ & $18.67 \mathrm{ab}$ & $6.03 \mathrm{ab}$ & $128.67 \mathrm{a}$ & $18.65 \mathrm{ab}$ & $2.50 \mathrm{bcd}$ \\
$50 \mathrm{t} / \mathrm{ha}$ at sowing & $18.33 \mathrm{a}$ & $27.00 \mathrm{a}$ & $5.70 \mathrm{~b}$ & $66.00 \mathrm{ab}$ & $27.05 \mathrm{a}$ & $2.83 \mathrm{bcd}$ \\
$50 \mathrm{t} / \mathrm{ha}$ at $1 \mathrm{WAS}$ & $18.00 \mathrm{a}$ & $27.00 \mathrm{a}$ & $4.20 \mathrm{~b}$ & $129.67 \mathrm{a}$ & $27.05 \mathrm{a}$ & $2.62 \mathrm{bcd}$ \\
$50 \mathrm{t} / \mathrm{ha}$ at $2 \mathrm{WAS}$ & $4.00 \mathrm{e}$ & $10.00 \mathrm{abc}$ & $2.67 \mathrm{~b}$ & $69.20 \mathrm{ab}$ & $11.00 \mathrm{ab}$ & $0.67 \mathrm{bcd}$ \\
$30 \mathrm{t} / \mathrm{ha}$ at $2 \mathrm{WBS}$ & $12.83 \mathrm{abc}$ & $21.33 \mathrm{ab}$ & $4.53 \mathrm{~b}$ & $94.03 \mathrm{ab}$ & $21.33 \mathrm{ab}$ & $5.83 \mathrm{a}$ \\
$30 \mathrm{t} / \mathrm{ha}$ at $1 \mathrm{WBS}$ & $10.00 \mathrm{abcde}$ & $11.67 \mathrm{abc}$ & $6.53 \mathrm{ab}$ & $96.27 \mathrm{ab}$ & $11.67 \mathrm{ab}$ & $2.38 \mathrm{bcd}$ \\
$30 \mathrm{t} / \mathrm{ha}$ at sowing & $11.00 \mathrm{abcde}$ & $26.00 \mathrm{a}$ & $6.43 \mathrm{ab}$ & $99.70 \mathrm{ab}$ & $26.50 \mathrm{a}$ & $3.55 \mathrm{ab}$ \\
$30 \mathrm{t} / \mathrm{ha}$ at $1 \mathrm{WAS}$ & $13.53 \mathrm{abc}$ & $20.33 \mathrm{ab}$ & $4.53 \mathrm{~b}$ & $97.47 \mathrm{ab}$ & $20.83 \mathrm{ab}$ & $0.17 \mathrm{~d}$ \\
$30 \mathrm{t} / \mathrm{ha}$ at $2 \mathrm{WAS}$ & $8.17 \mathrm{bcde}$ & $1.67 \mathrm{c}$ & $1.63 \mathrm{~b}$ & $92.97 \mathrm{ab}$ & $2.17 \mathrm{~b}$ & $0.17 \mathrm{~d}$ \\
$0 \mathrm{t} / \mathrm{ha}$ at $2 \mathrm{WBS}$ & $5.00 \mathrm{de}$ & $9.00 \mathrm{abc}$ & $2.13 \mathrm{~b}$ & $55.83 \mathrm{~b}$ & $9.50 \mathrm{ab}$ & $0.33 \mathrm{~cd}$ \\
$0 \mathrm{t} / \mathrm{ha}$ at $1 \mathrm{WBS}$ & $5.00 \mathrm{de}$ & $11.67 \mathrm{abc}$ & $4.13 \mathrm{~b}$ & $66.57 \mathrm{ab}$ & $12.17 \mathrm{ab}$ & $0.45 \mathrm{~cd}$ \\
$0 \mathrm{t} / \mathrm{ha}$ at sowing & $10.33 \mathrm{abcde}$ & $10.00 \mathrm{abc}$ & $10.67 \mathrm{a}$ & $50.33 \mathrm{~b}$ & $10.50 \mathrm{ab}$ & $0.45 \mathrm{~cd}$ \\
$0 \mathrm{t} / \mathrm{ha}$ at $1 \mathrm{WAS}$ & $6.00 \mathrm{cde}$ & $12.33 \mathrm{ab}$ & $6.67 \mathrm{ab}$ & $65.97 \mathrm{ab}$ & $12.83 \mathrm{ab}$ & $0.78 \mathrm{bcd}$ \\
$0 \mathrm{t} / \mathrm{ha}$ at $2 \mathrm{WAS}$ & $5.67 \mathrm{cde}$ & $7.33 \mathrm{abc}$ & $5.00 \mathrm{~b}$ & $59.00 \mathrm{~b}$ & $7.83 \mathrm{ab}$ & $1.55 \mathrm{bcd}$ \\
\hline
\end{tabular}

Means within the same column followed by the same letters are not significantly different at $\mathrm{P}=0.05$

Table 6. Responses of leaf Amaranth to application of poultry droppings at 9 WAS

\begin{tabular}{|c|c|c|c|c|c|c|}
\hline Treatments & $\begin{array}{l}\text { Plant } \\
\text { height (cm) }\end{array}$ & $\begin{array}{l}\text { Number } \\
\text { of leaves }\end{array}$ & $\begin{array}{l}\text { Stem } \\
\text { girth }(\mathbf{c m})\end{array}$ & $\begin{array}{l}\text { Leaf } \\
\text { area }\left(\mathrm{cm}^{2}\right)\end{array}$ & $\begin{array}{l}\text { Number of } \\
\text { Harvested stands }\end{array}$ & $\begin{array}{l}\text { Marketable } \\
\text { Yield (MT/ha) }\end{array}$ \\
\hline $50 \mathrm{t} / \mathrm{ha}$ at $2 \mathrm{WBS}$ & $15.63 a$ & $16.00 \mathrm{abc}$ & $5.63 \mathrm{a}$ & 93.47ab & 20.00ab & $2.28 \mathrm{a}$ \\
\hline $50 \mathrm{t} / \mathrm{ha}$ at $1 \mathrm{WBS}$ & $13.67 \mathrm{ab}$ & 14.33abcde & $5.00 \mathrm{ab}$ & $123.67 \mathrm{a}$ & $18.67 \mathrm{ab}$ & $1.28 \mathrm{a}$ \\
\hline $50 \mathrm{t} / \mathrm{ha}$ at sowing & $16.00 \mathrm{a}$ & $21.67 \mathrm{a}$ & $4.13 \mathrm{abc}$ & 61.00ab & $26.00 \mathrm{a}$ & $2.00 \mathrm{a}$ \\
\hline $50 \mathrm{t} / \mathrm{ha}$ at $1 \mathrm{WAS}$ & $15.67 \mathrm{a}$ & $16.33 \mathrm{abc}$ & $2.80 \mathrm{bcd}$ & $124.67 \mathrm{a}$ & $26.00 \mathrm{a}$ & $1.55 \mathrm{a}$ \\
\hline $50 \mathrm{t} / \mathrm{ha}$ at $2 \mathrm{WAS}$ & $3.03 \mathrm{~d}$ & $8.33 \mathrm{bcde}$ & $1.33 \mathrm{~d}$ & 63.53ab & $10.00 \mathrm{ab}$ & $0.67 \mathrm{a}$ \\
\hline $30 \mathrm{t} / \mathrm{ha}$ at $2 \mathrm{WBS}$ & 10.63abcd & $18.67 \mathrm{ab}$ & $4.33 \mathrm{abc}$ & $89.20 \mathrm{ab}$ & 21.33ab & $2.05 \mathrm{a}$ \\
\hline $30 \mathrm{t} / \mathrm{ha}$ at $1 \mathrm{WBS}$ & 8.57abcd & 8.67abcde & $5.40 \mathrm{a}$ & $91.27 \mathrm{ab}$ & $11.67 \mathrm{ab}$ & $0.88 \mathrm{a}$ \\
\hline $30 \mathrm{t} / \mathrm{ha}$ at sowing & $14.33 \mathrm{ab}$ & 18.33ab & $5.00 \mathrm{ab}$ & $94.70 \mathrm{ab}$ & $27.00 \mathrm{a}$ & $2.83 \mathrm{a}$ \\
\hline $30 \mathrm{t} / \mathrm{ha}$ at $1 \mathrm{WAS}$ & 12.33abcd & 15.67abcd & $4.00 \mathrm{abc}$ & $92.33 \mathrm{ab}$ & 20.33ab & $1.55 \mathrm{a}$ \\
\hline $30 \mathrm{t} / \mathrm{ha}$ at $2 \mathrm{WAS}$ & $6.77 \mathrm{bcd}$ & $1.67 \mathrm{e}$ & $1.33 \mathrm{~d}$ & 87.97ab & $1.67 \mathrm{~b}$ & $2.12 \mathrm{a}$ \\
\hline $0 \mathrm{t} / \mathrm{ha}$ at $2 \mathrm{WBS}$ & $3.63 \mathrm{~d}$ & $4.33 \mathrm{cde}$ & $1.50 \mathrm{~d}$ & $50.83 b$ & $9.00 \mathrm{ab}$ & $0.55 \mathrm{a}$ \\
\hline $0 \mathrm{t} / \mathrm{ha}$ at $1 \mathrm{WBS}$ & $4.70 \mathrm{~cd}$ & $4.00 \mathrm{cde}$ & $2.67 \mathrm{bcd}$ & $61.73 \mathrm{ab}$ & $11.67 \mathrm{ab}$ & $2.33 \mathrm{a}$ \\
\hline $0 \mathrm{t} / \mathrm{ha}$ at sowing & $7.00 \mathrm{bcd}$ & $8.00 \mathrm{bcde}$ & $3.47 \mathrm{abcd}$ & $32.67 \mathrm{~b}$ & $10.00 \mathrm{ab}$ & $1.67 \mathrm{a}$ \\
\hline $0 \mathrm{t} / \mathrm{ha}$ at $1 \mathrm{WAS}$ & $6.67 \mathrm{bcd}$ & $4.33 \mathrm{cde}$ & $2.43 \mathrm{~cd}$ & $60.97 \mathrm{ab}$ & $12.33 \mathrm{ab}$ & $2.33 \mathrm{a}$ \\
\hline $0 \mathrm{t} / \mathrm{ha}$ at $2 \mathrm{WAS}$ & 9.87abcd & $2.67 \mathrm{de}$ & $2.67 \mathrm{bcd}$ & $54.00 \mathrm{~b}$ & 7.33ab & $2.67 \mathrm{a}$ \\
\hline
\end{tabular}

Means within the same column followed by the same letters are not significantly different at $\mathrm{P}=0.05$

\section{Discussion}

The best results for almost all the parameters measured in the study, were recorded from 50 and/or $30 \mathrm{MT} / \mathrm{ha}$ (Omolayo et al., 2011; Fawole, 2015) of poultry manure applied at sowing. These include the height of leaf amaranths, number of leaves, number of germinated and harvested amaranth stands and marketable yield. This excellent performance of poultry dropping applied at sowing confirmed the quick-releasing ability of the poultry manure (Soilfacts, 2012). The $50 \mathrm{MT} / \mathrm{ha}$ of poultry droppings applied at one week after sowing (1 WAS) was observed to be the best in the leaf areas of amaranth vegetables measured and recorded, though not significantly different from same rates applied at 1 and 2 weeks before sowing but this could be an indication that the nutrients in the organic material were readily available (Soilfacts, 2012) for the uptake of the vegetables at the peak of the nutrient requirement; thus confirming the quick-releasing ability of the poultry manure.

The better seed germination, growth and yield performances and responses of the leaf amaranth to poultry manure at $50 \mathrm{MT} / \mathrm{ha}$ applied at sowing over 30 and $50 \mathrm{MT} / \mathrm{ha}$ applied at 2 weeks before sowing (especially as 
recorded at 7 weeks after sowing) might mean that some of the volatile nutrients like $\mathrm{N}$ in form of uric acid which could turn to urea and then to gaseous ammonia might have volatilized under unfavorable weather or soil conditions (Soilfacts, 2012) before utilization by the vegetables. Moreover, the organic N fraction which gradually becomes available for the uptake of the vegetables as the manure decomposes (mineralizes) might not be readily available for the uptake of the vegetables as the mineralization rates depends on environmental conditions (Charles and Donald, 2012). Also, some other useful and essential nutrients might have been lost to the environment or washed away before utilization by the vegetables.

The highest number of germinated seeds (measured and indicated by number of vegetable stands harvested) recorded from the plots treated with $50 \mathrm{MT} / \mathrm{ha}$ applied at sowing nullified the initial thought of the amaranth seeds being burnt if it comes into direct contact with undecomposed poultry manure.

The least values for all parameters measured at 2 weeks after sowing, at either of the applied rates, could mean that application of poultry manure as a dressing material in the production of leaf amaranth may not be profitable, especially when applied after one week of sowing. On the other hand, poultry manure could be useful as a dressing material in the production of vegetables and crops with longer life span than amaranth.

\section{Conclusions and Recommendations}

The findings of the studies are summarized as follows:

The best values for almost all the parameters measured in the study, were recorded from 50 and/or 30 MT/ha of the poultry manure applied at sowing.

The nutrients in the organic material when applied at sowing were readily available for the uptake of the vegetables at the peak of the nutrient requirement (which was guessed to be between 2 and 3 weeks after sowing); thus confirming the quick-releasing ability of the poultry manure.

The least values for all parameters measured were recorded at 2 weeks after sowing, at either of the applied rates.

Application of poultry manure as a dressing material in the production of leaf amaranth may not significantly improve the growth and yield of the vegetable, especially when applied after one week of sowing.

Poultry manure could be useful as a dressing material in the production of vegetables and crops with longer life span than amaranth, for example, maize.

Undecomposed poultry manure, when in direct contact, may not have negative effects on tender growing crops or germinating seeds.

If poultry manure were applied too much earlier than sowing or planting of crops, volatile nutrients like $\mathrm{N}$ in poultry manure could volatilize under unfavorable weather or soil conditions, before utilization by crops.

The 50 and/or $30 \mathrm{MT} / \mathrm{ha}$ of the poultry manure applied at sowing is recommended for improved and sustainable production of leaf Amaranth (Amaranthus hybridus).

\section{References}

Adeoluwa, O. O., \& Adeogun, O. O. (2010). Evaluation of feather as organic fertilizers on Amaranthus (Amaranthus caudatus). In the Proceedings of the First Technical Workshop on Organic Agriculture held at Ladoke Akintola University of Technology, Ogbomoso, Nigeria.

Adekiya, A. O., \& Agbede, T. M. (2017). Effect of methods and time of poultry manure application on soil and leaf nutrient concentrations, growth and fruit yield of tomato (Lycopersicon esculentum Mill). Journal of the Saudi Society of Agricultural Sciences, 16(4), 383-388. https://doi.org/10.1016/j.jssas.2016.01.006

Adeoye, G. O., Ojobor, S. A., \& AdeOluwa, O. O. (2004). Evaluation of potential of co-compost of rice waste, cow dung and poultry manure for production of rice. In Proceedings of the 29th Annual Conference of the Soil Science Society of Nigeria held December 6-10, 2004 at University of Agriculture, Abeokuta, Nigeria. pp. 213-218.

Aderolu, I. A., Omooloye, A. A., \& Okelana, F. A. (2013). Occurrence, abundance and control of the major insect pests associated with amaranth in Ibadan, Nigeria. Journal of entomology, Ornithology and Herpetology: Current research. https://doi.org/10.4172/2161-0983.1000112

Agunsoye, J. K., Salami, A. E., \& Tijani-Eniola, H. (2009). The influence of different nutrient sources on the performance of maize intercropped with other arable crops. In Proceedings of the 33rd Annual Conference 
of the Soil Science Society of Nigeria held March 9-13, 2009 at University of Ado-Ekiti, Nigeria. pp. 232-239.

Ahmad, A. A., Radovich, T. J. K., Nguyen, H. V., Uyeda, J., Arakaki, A., Cadby, J., Paull, R., Sugano, J., \& Teves, G. (2016). Use of Organic Fertilizers to Enhance Soil Fertility, Plant Growth, and Yield in a Tropical Environment, Organic Fertilizers. From Basic Concepts to Applied Outcomes, Marcelo L. Larramendy and Sonia Soloneski, IntechOpen. https://doi.org/10.5772/62529

Ahn, P. M. (1993). West African Soils. Oxford University Press, London. pp. 33-36.

Alasiri, K. O., \& Ogunkeyede, O. O. (1999). Effect of different levels of poultry manure on seed yield of okra. In Proceedings of the 25thAnnual Conference of the Soil Science Society of Nigeria held November 21-25, 1999 at Palm Royal Hotel, Benin City, Nigeria. pp. 102-108.

Alfred, E. H. (2006). Soil Fertility Decline: Definitions and Assessment. ISRIC- World Soil Information, Wageningen, The Netherlands.

Allain, A. (2004). Maintaining soil fertility in Africa. Retrieved from http://www.wrenmedia

Ano, A. O., \& Agwu, J. A. (2006). Effects of animal manures on selected soil properties: nitrogen, potassium and phosphorus. Nigerian Journal of Soil Science, 16, 145-150.

Busari, M. A., Adekunle, I. O., \& Azeez, J. O. (2004). Effects of poultry manure and phosphorus application on the productivity and fodder quality of two centrosema species in an Alfisol. In Proceedings of the 29th Annual Conference of the Soil Science Society of Nigeria held December 6-10, 2004 at the University of Agriculture, Abeokuta, Nigeria. pp. 133-138.

Charles, C. M., \& Donald, O. J. (2012). The value and use of poultry manures as fertilizers. Retrieved from http://hubcap.clemson.edu/ blpprt/Aub+244.html

Drinkwater, L. E., Wagoner, P., \& Sarrantonio, M. (1998). Legume-based cropping systems have reduced carbon and nitrogen losses. Nature, 396, 262-265. https://doi.org/10.1038/24376

Eneje, R. C., \& Azu, D. E. O. (2009). Algal compost effects on soil nutrient status and aggregate stability. Nigerian Journal of Soil Science, 19(2), 88-95.

FAO/UNESCO. (1988). Soil Map of the World. In World Soil Resources Report 60. Rome, Italy.

Fawole, F. O. (2015). Main and Residual Effects of Broiler Droppings on Some Soil's Physical and Chemical Properties and on the Growth and Marketable Yield of Leaf Amaranth (Amaranthus Cruentus (Hybridus) L) Amaranthaceae. International Journal of Research in Agriculture and Forestry, 2(9), 23-30.

Fawole, F. O., Ayodele, O. J., \& Adeoye, G. O. (2019). Soil Nitrogen Contents as affected by Composts Enriched with Organic Nitrogen Sources. Journal of Experimental Agriculture International, 34(3), 1-11. https://doi.org/10.9734/jeai/2019/v34i330177

Fawole, F. O., Ayodele, O. J., \& Adeoye, G. O. (2021). Available Phosphorus in Soils Amended with Organic N-Enriched Composts during Periods of Incubation. Journal of Plant Studies, 10(2), 20-29. https://doi.org/10.5539/jps.v10n2p20

Fasina, A. S., Aruleba, J. O., Omolayo, F. O., Omotoso, S. O., Shittu, O. S., \& Okusami, T. A. (2005). Properties and classification of five soils formed on granitic parent material of humid Southwest Nigeria. Nigeria Journal of Soil Science, 15(2), 21-29.

Grubben, G. J. H. (2004). Amaranthus cruentus L. (Internet) Record from PROTA4U. In G. J. H. Grubben \& O. A. Denton (Eds.), PROTA (Plant resources of Tropical Africa). Wageningen, Netherlands. Retrieved from https://uses.plantnet-project.org/en/Amaranthus_cruentus

Gruda, N. (2005). Impact of environmental factors on product quality of greenhouse vegetables for fresh consumption. Plant Science, 24(3), 227-247. https://doi.org/10.1080/07352680591008628

Hartemink, A. E. (2004). Nutrient stocks of short-term fallows on a high base status soil in the humid tropics of Papua New Guinea. Agroforestry Systems, 63, 33-43. https://doi.org/10.1023/B:AGFO.0000049431.12758.01

Hartemink, A. (2006). Soil Fertility Decline: Definition and assessment ISRIC-World soil information 6700 AJ Wageningen, The Netherlands. Encyclopedia of soil science D6110. https://doi.org/10.1201/NOE0849338304.ch339

Hossain, M. Z., Fragstein, P., Niemsdorff, P., \& Heb, J. (2017). Effect of Different Organic Wastes on Soil 
Properties and Plant Growth and Yield: a Review. https://doi.org/10.1515/sab-2017-0030

International Institute of Tropical Agriculture (IITA). (1982). Selected Methods for Soil Analysis. International Institute of Tropical Agriculture, Ibadan, Nigeria.

Isherwood, K. F. (2000). Fertilizer Use and the Environment. International Fertilizer Industry Association. Revised edition. Paris, France.

Martirosyan, D. M., Miroshnichenko, L. A., Kulakova, S. N., Pogojeva, A. V., \& Zoloedov, V. I. (2007). Amaranth oil application for coronary hearth disease and hypertension. Lipids Health in Disease, 6, 1. https://doi.org/10.1186/1476-511X-6-1

Naishima, A. S. I., Kalu, P. M., \& Igba, A. J. (2019). Assessment of Seed Germination and Organic Manure Application on the Early Growth of Eucalyptus camaldulensis L. Seedlings. Research Journal of Forestry, 13, 1-8. https://doi.org/10.3923/rjf.2019.1.8

Ndukwe, O. O., Muoneke, C. O., \& Baiyeri, K. P. (2011). Effect of the time of poultry manure application and cultivar on the growth, yield and fruit quality of plantains (Musa spp. AAB). Tropical and Subtropical Agroecosystem, 14, 261-270.

Olufolaji, A. O., \& Denton, O. A. (2000). Nigeria's most important vegetable crops. In M. O. Akoroda (Ed.), Agronomy in Nigeria (pp. 85-93). Department of Agronomy, University of Ibadan, Nigeria.

Olufolaji, A. O., \& Okelana, O. A. (2001). Grain Amaranth (Amaranthus cruentus, L) response to plant density and phosphorus nutrition under the humid condition of South-Western Nigeria. Nigeria Journal of Horticultural Sciences, 6, 58-66.

Omolayo, F. O., Ayodele, O. J., Fasina, A. S., \& Godonu, K. (2011). Effects of poultry manure from different sources on the growth and marketable yield of leaf amaranth (Amaranthus cruentus (hybridus) 1 ) amaranthaceae. International Research Journal of Agricultural Science and Soil Science, 1(2), 029-034.

Pacini, C, A., Wossink, G., Giesen, C. V., \& Huirne, R. (2003). Evaluation of sustainability of organic integrated and conventional farming systems: a farm and field scale analysis. Agriculture, Ecosystems and Environment, 95(1), 273-288. https://doi.org/10.1016/S0167-8809(02)00091-9

Peter M., Thomas M., Frank C., \& Mc Connell, J. (2004). Fertilizer Facts- Form of Fertilizers and other Soil Amendments. Soil Science Programs, College of Agriculture and Life Sciences, University of Guam.

Pimentel, D., Hepperly, P., Hanson, J., Douds, D., \& Seidel, R. (2005). Environmental, energetic and economic comparisons of organic and conventional farming systems. Bio Science, 55(7), 573-582.

https://doi.org/10.1641/0006-3568(2005)055[0573:EEAECO]2.0.CO;2

Prabu, M. J. (2009). Benefits from Poultry Manure. The Hindu. Retrieved from http://www.thehindu.com/sci-tech/agriculture/article37016.ece

Putnam, D. H., Oplinger, E. S., Doll, J. D., \& Schulte, E. M. (2013). Amaranth. In alternative field crops manual. Retrieved from https://www.hort.purdue.edu/newcrop/afcm/amaranth.html

Smyth, A. J., \& Montgomery, R. F. (1962). Soils and Land Use in Central Western Nigeria, Ibadan.

Soilfacts. (2012). Poultry Manure as a Fertilizer Source. Retrieved from http://www.soil.ncsu.edu/publications/soilfacts/AG-439-05/html

Uche, O. (1991). Effect of poultry manure on the yield and component of yield of Amaranthus. Nigeria Farmers ' Journal, 11, 35 .

Udo, E. J., Ibia, T. O., Ogunwale, J. A., Ano, A. O., \& Esu, I. E. (2010). Manual of Soil, Plant and Water Analysis. Sibon Books Ltd, Lagos. pp. 183.

U.S. (2012). Department of Agriculture. Agriculture Research Service. Nutrient Data Laboratory. Retrieved from www.nal.usda.gov/fnic/foodcomp/data

Whitaker, J. M. (2001). Reversing Diabetes. New York: Warner Books.

Wood, R., Lenzen, M., Dey, C., \& Lundle, S. (2005). A comparative study of some environmental impacts of conventional and organic farming in Australia. Agricultural Systems, 89(2-3), 324-348. https://doi.org/10.1016/j.agsy.2005.09.007

Zingore, S. P., Mafongoya, P. M., \& Giller, K. F. (2003). Nitrogen mineralization and maize yield following application of tree pruning to a sandy soil in Zimbabwe. Agroforestry Systems, 57, 199-211. 
https://doi.org/10.1023/A:1024887225450

\section{Copyrights}

Copyright for this article is retained by the author(s), with first publication rights granted to the journal.

This is an open-access article distributed under the terms and conditions of the Creative Commons Attribution license (http://creativecommons.org/licenses/by/3.0/). 